
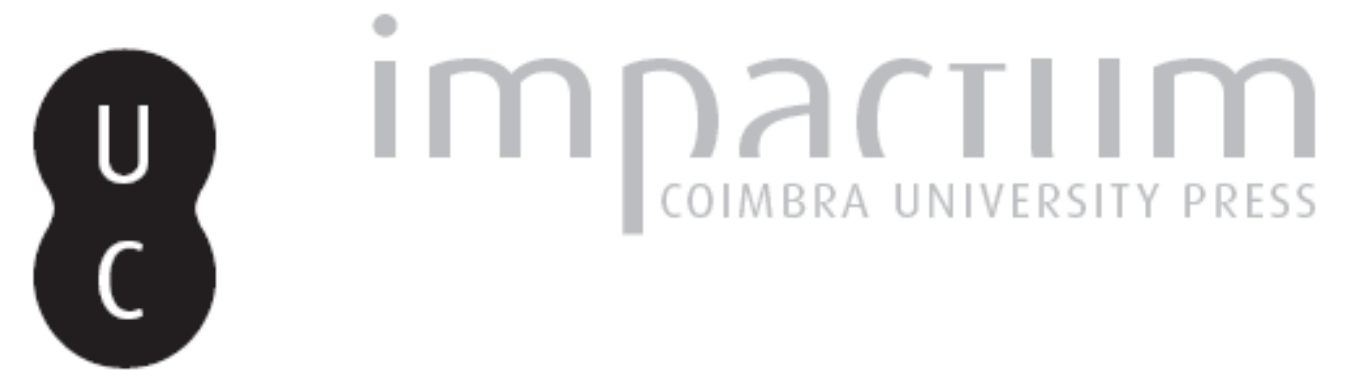

\title{
Plutarch and 'God-Eclipse' in christian Theology
}

Autor(es): Zuiddam, Benno A.

Publicado por: International Plutarch Society

URL persistente:

URI:http://hdl.handle.net/10316.2/36395

DOI:

DOI:http://dx.doi.org/10.14195/0258-655X_6_6

Accessed : $\quad$ 26-Apr-2023 09:48:24

A navegação consulta e descarregamento dos títulos inseridos nas Bibliotecas Digitais UC Digitalis, UC Pombalina e UC Impactum, pressupõem a aceitação plena e sem reservas dos Termos e Condições de Uso destas Bibliotecas Digitais, disponíveis em https://digitalis.uc.pt/pt-pt/termos.

Conforme exposto nos referidos Termos e Condições de Uso, o descarregamento de títulos de acesso restrito requer uma licença válida de autorização devendo o utilizador aceder ao(s) documento(s) a partir de um endereço de IP da instituição detentora da supramencionada licença.

Ao utilizador é apenas permitido o descarregamento para uso pessoal, pelo que o emprego do(s) título(s) descarregado(s) para outro fim, designadamente comercial, carece de autorização do respetivo autor ou editor da obra.

Na medida em que todas as obras da UC Digitalis se encontram protegidas pelo Código do Direito de Autor e Direitos Conexos e demais legislação aplicável, toda a cópia, parcial ou total, deste documento, nos casos em que é legalmente admitida, deverá conter ou fazer-se acompanhar por este aviso.

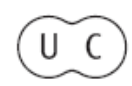




\section{PLOUTARCHOS, n.s.}

Scholarly Journal o

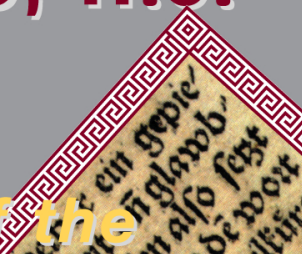

INTERNATIONAL PLUT A N NOS

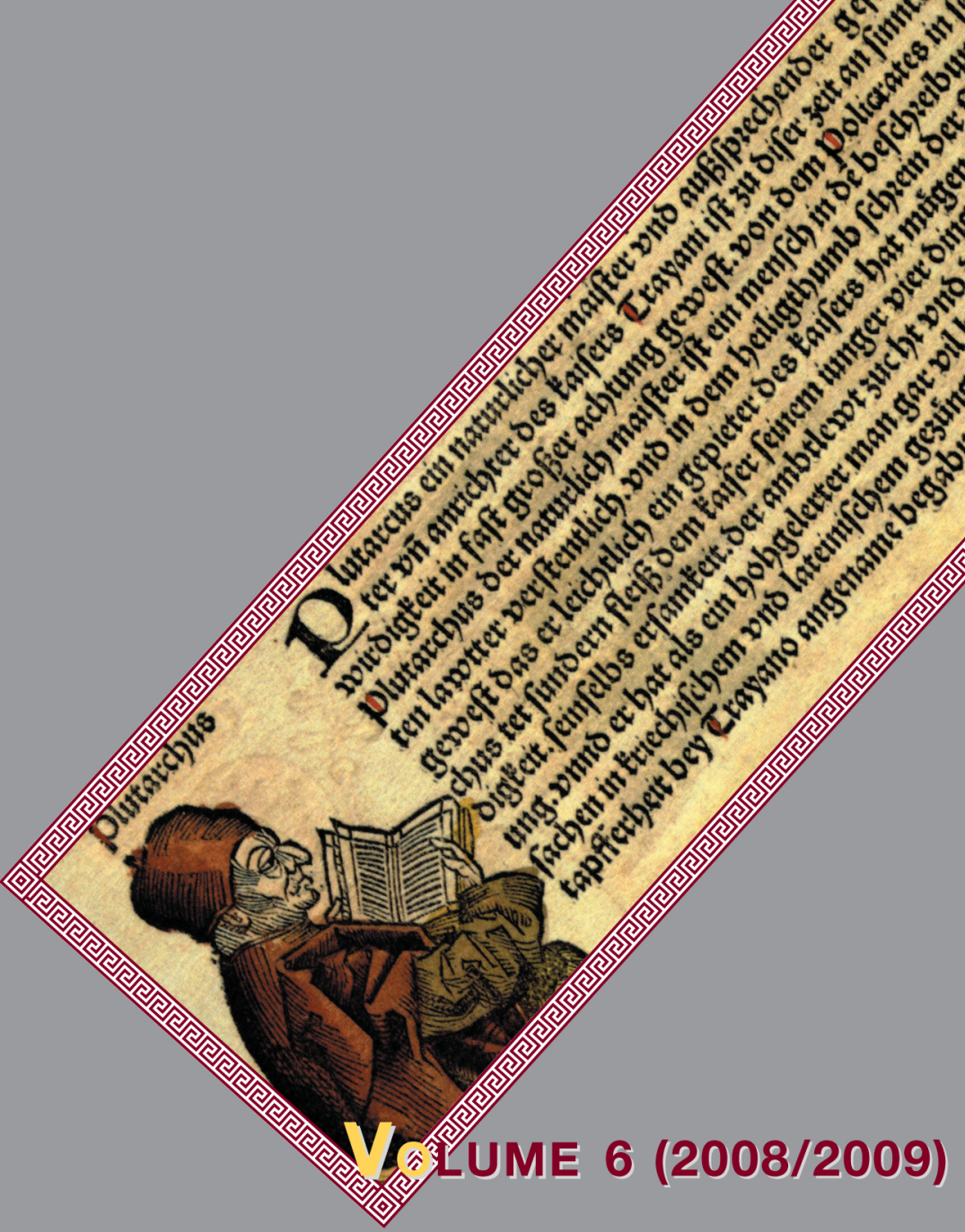

UNIVERSITY of Málaga (SPAin)

Utah State UniVersity, Logan, Utah (U.S.A.) 


\title{
Plutarch and 'God-Eclipse' in Christian Theology by \\ Benno A. Zuiddam \\ Nord-West University South-Africa \\ Benno.Zuiddam@nwu.ac.za
}

\begin{abstract}
This article calls attention to the importance of Plutarch's book De Defectu Oraculorum as a primary source on the development of the Greek oracle religion in the first century. It argues with an abundance of data from this historic literary document that Plutarch experienced a profound crisis about the disappearance of the oracles. This article also establishes that Plutarch's view on the cessation of the oracles in the first century cannot be satisfactorily explained in terms of lack of interest and the influences of Roman thought and politics. On a level of religious experience, Plutarch's ideas prove stimulating for the consideration of the recent "God eclipse" in Christian theology.

Key-Words: Plutarch, Oracles, God-eclipse, Delphi, Apollo, Pythia, Pan, Cicero, Defectu Oraculorum, Theology.
\end{abstract}

\section{De Defectu Oraculorum in popular scholarship}

On the Cessation of Oracles is a dialogue, discussing the reasons why divine inspiration seemed to be withdrawn from the old seats of prophetic lore. The real reason of their decline in popularity is probably very simple; when the Greek cities became Roman provinces the fashion of consulting oracles fell off, as unsuited to the more practical influences of Roman thought and Roman politics.

In this way the classic Encyclopaedia Britannica (11th edition volume 25, 860) summarises a popular view about Plutarch's book De Defectu Oraculorum (On the Cessation of the Oracles). This has more recently been abridged into:

On the Failure of the Oracles, in which the decline of the oracles is linked with the decline in population" (Encyclopaedia Britannica 2002, volume 9:529). 
This paper will show that none of these of the Greek oracle religion that was qualify as a fair summary of the literary signalled before and after. Even artificial document. However prevalent such natu- revival did not bring a lasting change.

ralistic explanations for the cessation of oracles in the first century continue to be, they are not Plutarch's. A careful examination of De Defectu Oraculorum shows that this ancient Greek author had a thoroughly religious explanation for the disappearance of the oracles. This article argues this as it closely follows the primary source on this subject.

\section{Preliminary remarks Greco-Roman setting}

To provide the necessary historical to the purpose of his god ${ }^{3}$. Plutarch's book and religious context, a few preliminary about the disappearance of the oracles remarks about the Greco-Roman setting should be read in its spiritual context. of Plutarch's book are in order. De Defectu Oraculorum has a profoundly religious author. It is placed in a historically

2.2 Religious setting

Traditionally the Greeks believed that important religious setting and was written the gods revealed their will at special during an adverse historical development sites, in English commonly referred to as

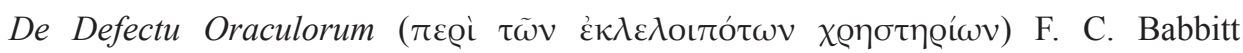
translates "On the Obsolescence of the Oracles" (Plutarch 2003:347-501). Plutarch uses $\varepsilon \kappa \lambda \varepsilon \lambda$ oı $\pi$ ó $\tau \omega \nu$ in the sense of vanishing altogether. FLACELIÈRE's edition (1947) gives the more accurate translation "Sur la disparation des oracles." See also for example:

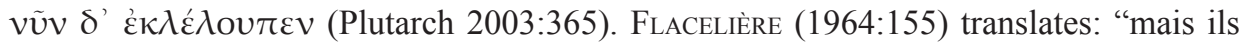
ont maintenant disparu,» «but at the present time these have vanished altogether.» This is followed by Rescigno's (1995) more recent text-edition, which speaks about «eclissi degli oracoli," or "the disappearance of the oracles".

2 Plutarch writes elsewhere (De Pythiae Oraculis 409B/C): "But for us the god grants clearer, stronger, and plainer evidence than this by bringing about after a drought, so to speak, of earlier desolation and poverty, affluence, splendour and honour" (2003:343).

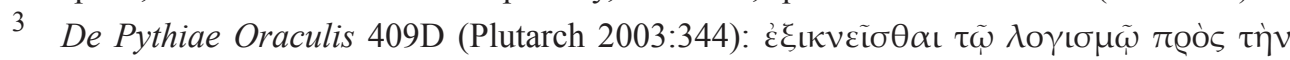

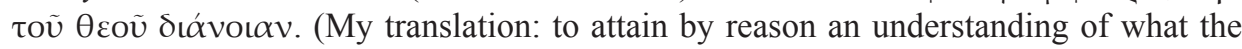
god has in mind.). 
"oracles". These sites were determined be read in a context of an adverse historical by the gods and as a result of this, the site development. It was a sign of decline in was an essential element of the oracular the Greek oracle religion that it had lost process. The availability of divine di- most of its directive influence on political rection was limited by the geographical and military life. By the first century BC, location. At many of those sites the the once sacred oracles were even openly gods used human media to pass on their criticized in prominentcircles. The famous messages. But whether indirectly through philosopher and statesman Marcus Tullius a medium, or directly by means of a Cicero (106-43BC) enables his readers dream to the enquirer, it was always the to view the oracle in Delphi through the oracular site that functioned as a 'port key' eyes of himself and his brother Quintus between the Greeks and their god. The Tullius Cicero (102 BC - 43 BC). This local setting of De Defectu Oraculorum younger brother is mentioned by Julius is Delphi, the site of the most famous Caesar as a brave military leader (Bello oracle in Greek history. As this site was Gallico 5.52) ${ }^{4}$. Cicero's work signals that dedicated to Apollo, and Apollo was the ancient oracle religion was in decline the main god for divination, one would by the first century BC. ${ }^{5}$ To explain this, expect a prominent role for this deity in Quintus even suggested that the flow of De Defectu Oraculorum.

\subsection{Historical decline} the inspirational gasses at Delphi must have been affected in the course of history: "The subterraneous exhalations

Plutarch's book about the disappea- which used to kindle the soul of the rance of the oracles is not only a religious Pythian princess with divine inspiration book by a religious author. It should also have gradually vanished in the long lapse

4 Commentarii de Bello Gallico 5.52: Ciceronem pro eius merito legionemque collaudat. (Translation: He commends Cicero for his merits and the legion as well.) Online: http:// digilander.libero.it/jackdanielspl/Cesare/gallico/liber_5.htm.

5 De Divinatione 18.37-38: defendo unum hoc numquam illud oraclum Delphis tam celebre et tam clarum fuisset neque tantis donis refertum omnium populorum atque regum, nisi omnis aetas oraclorum illorum veritatem esse experta. „Idem iam diu non facit." Ut igitur nunc minore gloria est, quia minus oraculorum veritas excellit, sic tum, nisi summa veritate, in tanta gloria non fuisset. Green (2001:112): „The oracle in Delphi would never have been so much frequented, so crowded with offerings from peoples and kings of every land, if all ages had not tested the truth of its prophecies. [But today that is no longer the case.] Therefore, as at present its glory has waned, because it is no longer noted for the truth of its prophecies." Online: http://www.thelatinlibrary.com/ cicero/divinatione1.shtml\#18. 
of time" (Green 2001:112) ${ }^{6}$.

A century later even Plutarch admitted that the questions still put to the oracle in Delphi were mostly of a trivial nature. It seemed that no one was willing to trust Apollo for really crucial decisions in the life of the nation anymore. In his book De Pythiae Oraculis (about the fact that the oracles at Delphi are no longer given in verse), Plutarch (2003:336-338,408C) writes: "Where there is nothing complicated or secret or terrible, but the interrogations are on slight and commonplace matters, like the hypothetical questions in school: if one ought to marry, or to start on a voyage, or to make a loan; and the most important consultations on the part of the State's concern the yield from crops, the increase of herds, and public health." people today may not consider these matters trivial, Plutarch clearly did, as he remembered that the oracles used to play a far greater role. What is more, Plutarch also voiced concern about the Pythia losing her power in De Pythiae Oraculis (397D, 402B; cf. Green 2001:115).

Early in the second century AD, Juvenal would publicly doubt whether there was still anything going on in Delphi at all (Satura 6.555.56, Green 2001:115) $)^{9}$.

De Divinatione 18.38: Potest autem vis illa terrae, quae mentem Pythiae divino adflatu concitabat, evanuisse vetustate, ut quosdam evanuisse et exaruisse amnes aut in alium cursum contortos et deflexos videmus. Sed ut vis acciderit (magna enim quaestio est), modo maneat id quod negari non potest nisi omnem historiam perverterimus: multis saeclis verax fuisse id oraculum. Online: http://www.thelatinlibrary.com/cicero/divinatione1.shtml\#18.

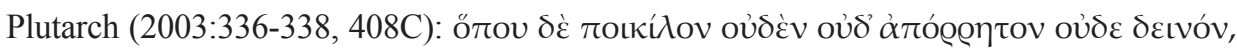

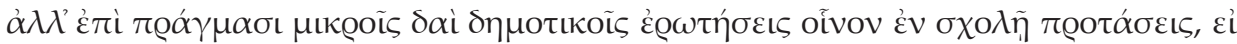

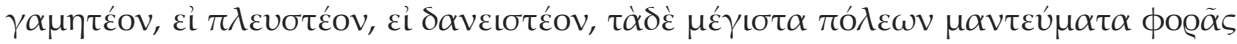

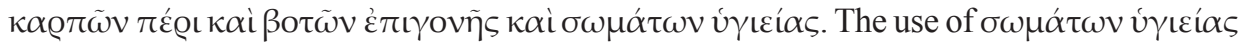
could also invite the translation "bodily health" instead of "public health".

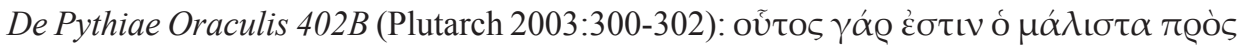

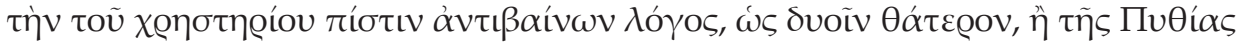

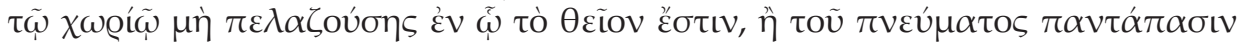

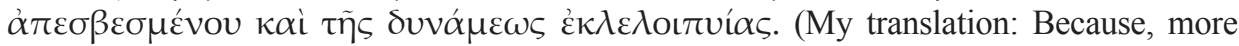
than anything else it is this matter that takes away confidence in the oracle, as if we face two possibilities: either that the Pythia does not come near to the region where the god is, or else that the spirit has been completely quenched and that the spiritual force has disappeared.).

Satura 6.555.56: quoniam Delphis oracula cessant et genus humanum damnat caligo futuri. (My translation: for now that Delphi's oracles have ceased, the human race is condemned to imperceptiveness about the future. Online: http://www.thelatinlibrary.com/ juvenal/6.shtml. 
These data about the religious context hear: "This same emperor gave 400,000 from Cicero to Juvenal show that De sesterces to the Pythia for uttering some Defectu Oraculorum is sanwiched in an oracles that suited him." ${ }^{.10}$. historical setting of profound decline in the Greek oracle religion. This indicates that Plutarch's voicing concern at this particular moment in time should not setting and the main characters of come as a surprise. It shows that $D e$ the book, this section shows from $D e$ Defectu Oraculoram naturally fits a late Defectu Oraculorum that Plutarch's book first century setting.

\subsection{Artificial revival}

As last preliminary remark, it should be realised that during Plutarch's life and after several emperors attempted to revive the oracles, but failed. It was their financial impetus rather than their spiritual input that led to renewed activity, but not to a lasting revival. Cassius Dio, in his Roman History 62.14.2 (Loeb volume around the Mediterranean, that several 8, 1925:161), describes how Nero paid learned men met in Delphi. This happened the Pythia to say what he wanted to shortly before the Pythian Games. These

10 Plutarch (2003:200-203) mentions Nero's visit in “The E at Delphi," but does not recall desecration of any sort. For this reason Dempsey (1918:177) questions Cassius Dio's account. On the other hand, it could be objected that Plutarch had every reason not to recall any untoward behaviour on the part of the powers that be, leaving it unmentioned as Nero had also shown himself supportive of the oracle cause. As a politician Plutarch may have valued imperial relations as a long-term strategy.

11 Both late and early dates for De Defectu Oraculorum have been advocated, but not conclusively; see Jones (1966:70; 1973:136). Following BARROw (1967), Jones's pupil, OGILVIE (1967:119) advocates a date of 83AD, and argues a case for 79AD and 87AD as outside possibilities. Barrow took De Defectu Oraculorum as the last of the Pythian dialogues and suggests a date of c. 84 AD, but according to ZIEGLER (1964:199), who suggests a date around $100 \mathrm{AD}$ this is quite arbitrary as the available data can be argued different ways. The meeting probably took place between 75 and $110 \mathrm{AD}$. Even the discovery of two bronze plates in York in 1860 (Russell 1973:12) that mention the name Demetrius, who has been identified as Plutarch's friend by some, does little to suggest a firmer date (BARROw 1967:25,34). 
took place every fourth year, in the months shared with Paul the Apostle. Plutarch's of August and September (Halsberghe \& other main guest came from the opposite De Waele 1989:33), probably during the direction. Cleombrotus the Lacedemonian Greek summer month of July. was returning to his native Sparta after

Plutarch himself was a bit of a scholar, combining the traits of a philosopher (RM Jones 1980:68-108), politician and priest (Ziegler 1964:24-25; CP Jones 1973:3132; RM Jones 1980:63-83) ${ }^{12}$. Two of his friends are described as well-travelled scholars. Plutarch calls them 'holy men' (Fowden 1982:33-59). Both were on their way home. The first was Demetrius the grammarian, who, after wandering in Western France perhaps even crossed the repute of the divine influence there, but English Channel. He was now on his way at the present time it has withered."13 home to Tarsus, a home town which he In other words, for Plutarch ${ }^{14}$ the oracle

That Plutarch was a priest is commonly assumed, but apart from one possible reference, Plutarch's works don't seem to claim this. His extensive writing on theological subjects, however, and his activities in Delphi established him as a religious authority. An inscription

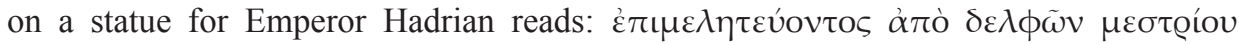

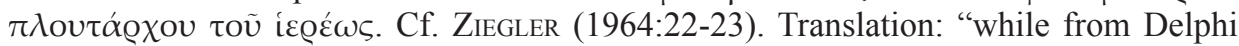
Mestrius Plutarch the priest was in charge as curator"(cf. LidDell \& ScotT 1996:645).

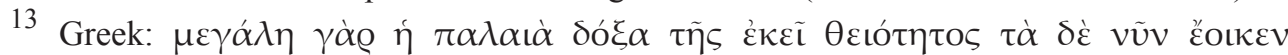

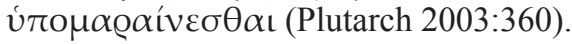

14 The author of De Defectu Oraculorum is consistently addressed as Lamprias. As Plutarch's authorship has never been the subject of serious debate, Lamprias should probably be identified with Plutarch himself. Some suggest that this Lamprias was Plutarch's brother or friend. If so, one should not just conclude that "Plutarch seldom appears in his dialogues, but Lamprias often enters as a spokesman" (BRENK 1973:7), but perhaps go as far as to state that in that case Plutarch himself is almost completely invisible. He may have drawn on the memoirs of his grandfather or brother, but De Defectu Oraculorum does not suggest this at all, nor does it make a distinction between the author and a separate spokesman. Lamprias was a (nick-) name that ran in Plutarch's family. It was not only used to address his grandfather and brother, but also Plutarch's son (BARROw 1967:193-194), but was probably used as means to address the author of De Defectu Oraculorum as well. Other names that feature in the discussion are Cleombrotus, Demetrius of Tarsus and Ammonius (by some seen as Plutarch's tutor, cf. SwaIN 1989:297), Didymus, Philip and Heracleon. Cf. BARRow (1967:33-34). 
seemed to have lost much of its divine power. Demetrius (Plutarch 2003:361), the grammarian, agrees and says:

There is no need to make any inquiries nor to raise any questions about the state of affairs there, when we see the fading away of the oracles here, or rather the total disappearance of all but one or two; but we should deliberate the reason why they have become so utterly weak." 15

Demetrius is able to mention a few inspired sayings of oracles in days long bygone, but continues (Plutarch 2003:365) to say:

There have been also more recent manifestations than these at these oracles, but now the oracles

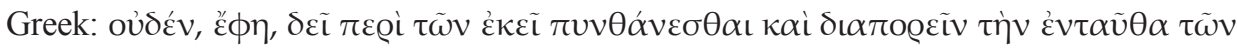

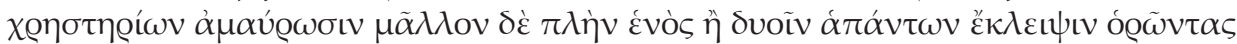

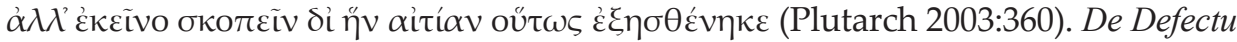
Oraculorum suggests a general cessation of genuine oracles in the Greco Roman world by the first century AD. The friends who allege this are members of the philosophical and religious elite and are presented as widely travelled, both in the West and the East, and considered representative for that reason. If Plutarch's observations in De Defectu Oraculorum_reflect the actual state of affairs around the turn of the first century, one should note that there is some evidence for a temporary revival of oracles in the second and third centuries. There has, however, been much debate to what extent this was 'organised' religion, funded by anti-Christian emperors to support their political strategies. According to NILSSON (1986:141) the decline of belief in oracles in general had already started centuries before Plutarch's day: "The belief in oracles declined in the fourth century B.C. but the desire to know the future was lasting." Nilsson supposes a decline in the fourth century on the basis of Plutarch's life of Demosthenes where the orator plays down an unfavourable oracle with the instrument of reason. The Thebans he reminded of Epaminondas, the Athenians of Pericles, who always preferred a rational approach and regarded oracles as mere pretexts for cowardice. As Pericles lived in the fifth century before Christ, Nilsson's thesis should perhaps be taken as a general indication of decline from c. 500 BC. One should realise, however, that Nilsson makes this suggestion on the basis of very limited data. The dialogue in De Defectu Oraculorum suggests more recent oracular activity than the fourth century BC. On the other hand, this could come under the category of lip service, as Delphi lay in ruins for the greater part of that century and nobody was willing or able to put any money towards restoring the sanctuary. Philosophical scepticism had become more profound too (DEMPSEY 1918:168). Nilsson explores the notion that decline is a process as well and emphasises that by the fourth century prominent leaders in Athens and Sparta publicly doubted the value of oracles without compromising their position in Greek society. This indicates a decline of authority. 
are no more; so it is well worth while, here in the precinct of the Pythian god, to examine into the reason for the change."16

\subsection{No practical expectation}

Although a suggestion to consult the oracle is made, it is most revealing about their levels of expectation that in Plutarch's account the oracle in fact never is consulted. After paying religious lip service, the friends continue to discuss the failure of the oracles. For reasons of respect, the oracle at Delphi is still revered with pious words, but for all practical intents and purposes there is no use in actually taking the trouble to consult it. The friends theorise about oracles, practicing philosophy and theology as adherents of the great Greek religion, but no longer expect Apollo to relate to them in real life.

3.4 A crisis of faith and a decrease in population
The disappearance of the oracles was a crisis of faith. Ammonius (Plutarch 2003:373) tried to work his way around it by blaming the decrease in population: "for the god's abandoning of many oracles is nothing other than his way of substantiating the desolation of Greece" (cf. Swain 1989:297) ${ }^{17}$. Ammonius admits (Plutarch 2003:375) that there is hardly a single prophetess left in oracular employ:

But today there is one priestess and we do not complain, for she meets every need. There is no reason, therefore, to blame the god; the exercise of the prophetic art which continues at the present day is sufficient for all, and sends away all with their desires fulfilled... ...we should needs be surprised at the god if he allowed his prophecies to run to waste, like water, or to echo like the rocks with the voices of shepherds and

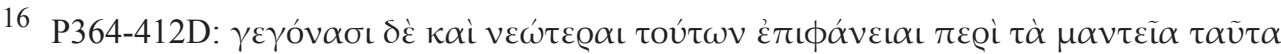

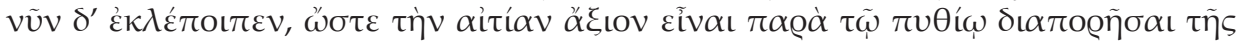
$\mu \varepsilon \tau \alpha \beta \mathrm{o} \tilde{\eta} \varsigma$.

17 Wood (2004:143) correctly argues that a crisis of faith is implied, rather than unwillingness on the part of the gods, but incorrectly introduces a secular cause for this: "The suggestion is that oracles are not because they are false or ineffective but because no one wants them anymore." Wood mistakenly attributes the explanation of decrease in population to Demetrius. According to De Defectu Oraculorum (2003:373) it was Ammonius who spoke these words. Wood (2004:143) also gives a naturalistic explanation for the cessation of the oracles: "What the devout Plutarch describes as the god's abandonment of the oracles, others might describe as the world's abandonment of the god. The world had other places to go." Ammonius, however, tried to make out a case for depopulation and not for disinterest. The 'others' in Wood's argument would refer to 21 st century scholars rather than any view presented in De Defectu Oraculorum. 
flocks in waste places." 18

In other words, nothing to worry about, the gods are still doing their job amply for the handful of people that are left in Greece. Waste not, want not.

\subsection{Daemons}

Initially, Plutarch (2003:375) meets of involuntary changes. Plutarch desired this way of reasoning with silence ${ }^{19}$. He to preserve divine involvement in the (Plutarch 2003:375-377) then introduces inspiration of the oracles and the things corruption as a factor. This leads the of earth in an indirect way. The gods friends to discuss the role of Providence are involved, but only through agents (Swain 1989:272-302), how the gods (Plutarch 2003:389) ${ }^{21}$. This shows that

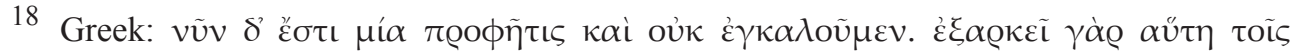

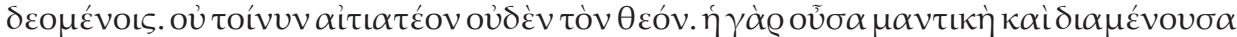

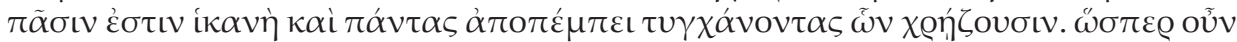

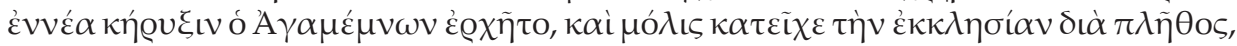

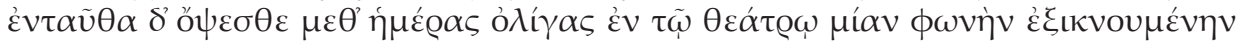

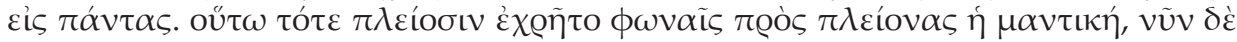

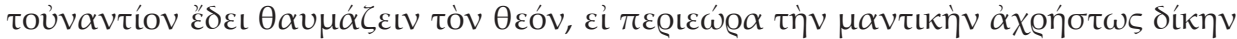

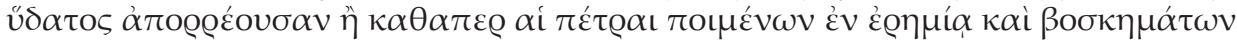
$\phi \omega v \alpha \tilde{i} \varsigma \alpha \dot{v} \tau \eta \chi 0 \tilde{\sigma} \sigma \alpha v$ (Plutarch 2003:374).

19 Cleombrotus subsequently addresses Plutarch. This shows that Plutarch was respected as their fellow and had probably reached a mature age. This is reinforced by the fact that Heracleon of Megara (Plutarch 2003:366-367) is specifically referred to as a young man (Plutarch 2003:398-399), indicating that Plutarch as the author must have passed this stage of life at the time of writing.

20 For daemons in Plutarch, see Russell (1973:75-79).

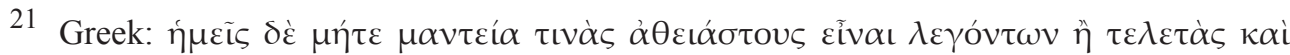

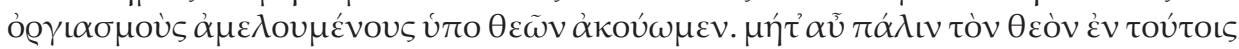

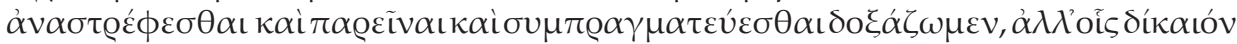

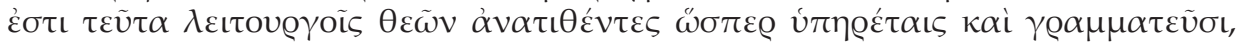

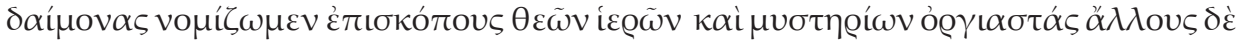

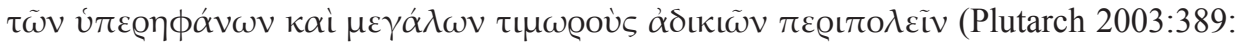
"But as for us, let us not listen to any who say that there are some oracles not divinely inspired, or religious ceremonies and mystic rites which are disregarded by the gods; and on the other hand let us not imagine that the god goes in and out and is present at these 
Plutarch is very anxious to ascribe a religious cause to the cessation of the oracles and is not satisfied with a mere naturalistic explanation. For this reason, and also because of the related issue of the mortality of the gods, it is important to establish the role of daemons in the argument of De Defectu Oraculorum.

\subsubsection{Mortality of daemons}

Cleombrotus agrees with Plutarch that the times hardly offer any good signs on the issue of divine activity at the sacred sites. On the contrary, extinction seems a fair way to describe the activities of the daemons at oracular sites. Cleombrotus (Plutarch 2003:397) blames the daemons:

Let this statement be ventured by us, following the lead of many others before us, that coincidently with the total defection of the guardian spirits assigned to the oracles and prophetic shrines, oc- curs the defection of the oracles themselves; and when the spirits flee or go to another place, the oracles themselves lose their power. ${ }^{22}$

Plutarch and Cleombrotus are even willing to consider the mortality of daemons. A young man present at the discussion, Heracleon, is not very happy with these thoughts at all. He considers the death of daemons, as if they were like mortal people, a "too audacious and uncivilized" 23 theory (Plutarch 2003:399).

\subsubsection{The great Pan is dead! ${ }^{24}$}

To defend his position on the mortality of daemons, Cleombrotus relates a supernatural event that took place in a previous generation. The father of a townsman of his travelled at sea, when the wind dropped and the current took them close to the Isle of Paxi in the Mediterranean. A voice called out three times to the pilot of the ship, an Egyptian, Thamus by

ceremonies and helps in conducting them; but let us commit these matters to those ministers of the gods to whom it is right to commit them, as to servants and clerks, and let us believe that demigods are guardians of sacred rites of the gods and prompters of the Mysteries, while others go about as avengers of arrogant and grievous cases of injustice.").

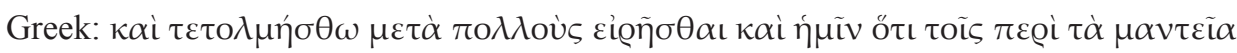

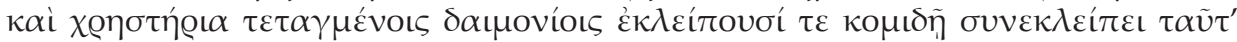

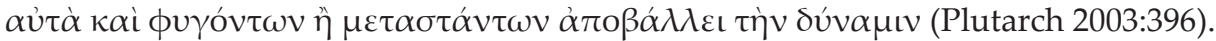

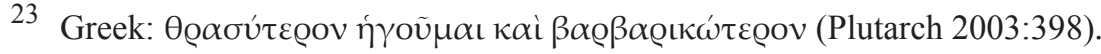

24 Greek: $\pi \dot{v} v$ ó $\mu \varepsilon ́ \gamma \alpha \varsigma \tau \dot{\varepsilon} \theta v \eta \kappa \varepsilon$ (Plutarch 2003:400). Interestingly, in the hills above Delphi lies the Korykian Cave, which some suggest to be the site of a dice oracle dedicated to Pan and the Nymphs (CuRNow 2004:58). 
name. When Thamus answered, the voice (Plutarch 2003:401) replied: "When you come opposite to Palodes, announce that Great Pan is dead." 25 The current took them to this place and Thamus cried out his message to the shore.

So, when he came opposite Palodes, and there was neither wind nor wave, Thamus from the stern, looking toward the land, said the words as he had heard them: 'Great Pan is dead.' Even before he had finished there was a great cry of lamentation, not of one person, but of many, mingled with exclamations of amazement.
As many persons were on the vessel, the story was soon spread abroad in Rome, and Thamus was sent for by Tiberius Caesar. Tiberius became so convinced of the truth of the story that he caused an inquiry and investigation to be made about Pan; and the scholars, who were numerous at his court, conjectured that he was the son born of Hermes and Penelope ${ }^{26}$ (Plutarch 2003:403).

The Church historian Eusebius of Caesarea would later connect the death of Pan with the ministry of exorcism ${ }^{27}$ by Christ in the Gospels ${ }^{28}$.

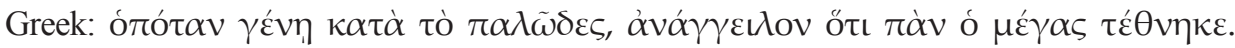
Much has been done to revive Pan in post-enlightenment literature (cf. IRWIN 1961:159-167).

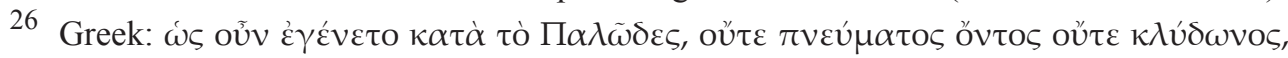

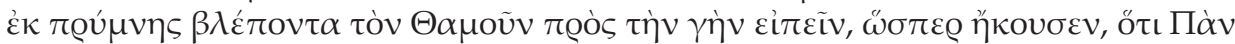

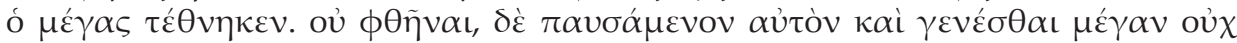

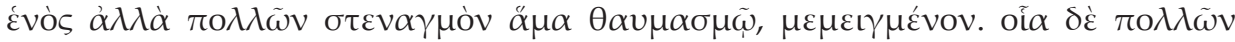

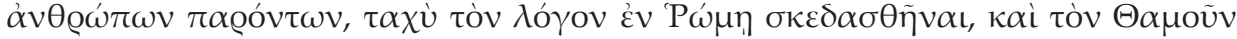

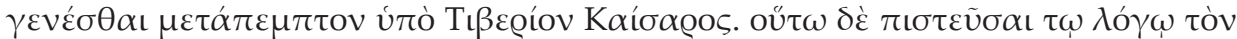

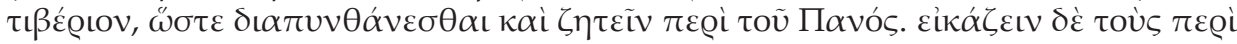

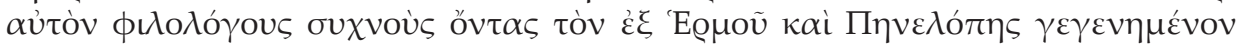
(Plutarch 2003:402).

27 Interestingly, it is in Plutarch (and not so much in earlier Greek writers) that Pan is associated with fear (cf. HARRISON 1926:6).

28 Eusebius calls Pan a daemon. After quoting Plutarch's De Defectu Oraculorum extensively (Eusebius 2006:104-106), Eusebius writes in his Preparatio Evangelica, book 5.17.13, 14:

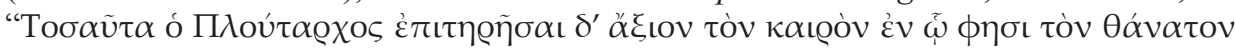

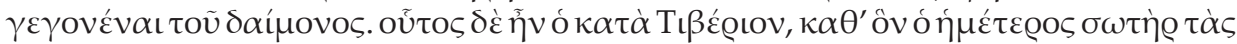

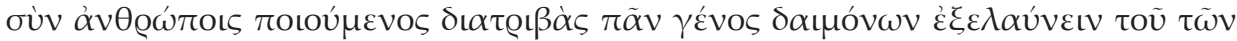

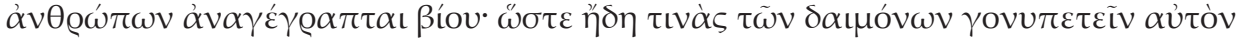

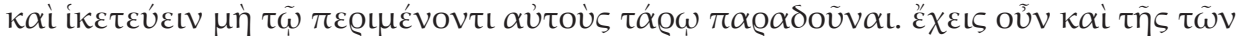

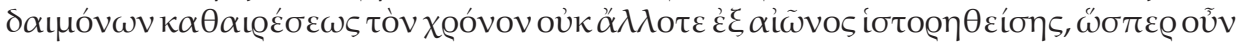

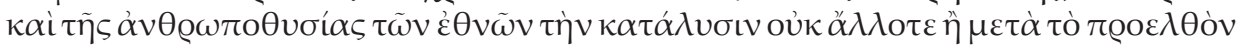

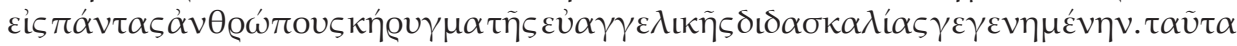




\subsection{Plutarch's ultimate crisis}

Although there may be many factors responsible for the apparent sense of failure of the oracles by the first century AD (cf. Dyer 1969:38-56; Hewitt 1912: 95-111), Plutarch takes us to the existence and wellbeing of the gods as the ultimate issue ${ }^{29}$. As he says goodbye to his readers, leaving Delphi and his learned friends, Plutarch concludes his book by saying that, despite all possible secondary means and causes, the power of an oracle comes from the gods and daemons (Plutarch 2003:501):

but, for all that, it is not unfailing nor imperishable nor ageless, lasting into that infinite time by which all things between earth and moon become wearied out, according to our reasoning. And there are some who assert that the things above the moon also do not abide, but give out as they confront the everlasting and infinite, and undergo continual transmutations and rebirths." 30

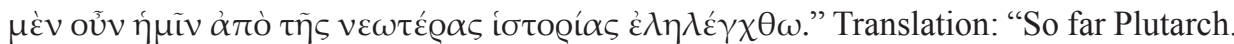
But it is important to observe the time at which he says that the death of the daemon took place. For it was the time of Tiberius, in which our Saviour, making His sojourn among men, is recorded to have been ridding human life from daemons of every kind, so that there were some of them now kneeling before Him and beseeching Him not to deliver them over to the Tartarus that awaited them. You have therefore the date of the overthrow of the daemons, of which there was no record at any other time; just as you had the abolition of human sacrifice among the Gentiles as not having occurred until after the preaching of the doctrine of the Gospel had reached all mankind. Let then these refutations from recent history suffice" (Gifford translation). Identifications of Pan's death with the crucifixion of Christ as the dying saviour seem to go back to Victorian and post-Victorian interpretations (Borgeaud 1983:254-283). A modern day exponent of the latter is S. Fontelieu. Based on a Jungian proposition, she (2007:98) concludes, "Pan did not die. He, like an echo, continues, as an elusive, wordless reverberation, a din just outside our hearing. The divinity of the chthonic side of our animal nature is not dead. The embodiment of the split between the divine and the animal nature is waiting, whispering to be echoed, to be redeemed. This action is a psychological problem for our time. Pan has stayed alive, furtively slinking about in the collective shadows, echoing the split in our nature and the intersection within of the human and the divine. In this, he is indeed like Christ on the cross, both human and divine, and like Christ, he died and like Christ, Pan did not die."

If Plutarch is not the person addressed as Lamprias (some suppose that Lamprias is Plutarch's brother, another friend or family member), the mere fact of Plutarch suddenly sharing his personal view to the reader at the end of the book, would seem an even more dramatic turn: an author who remains silent throughout the conversation, but has the last word by suggesting to the reader to contemplate the thought that the gods might be dying.

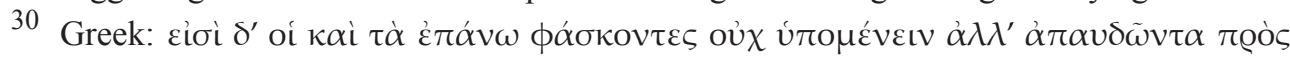

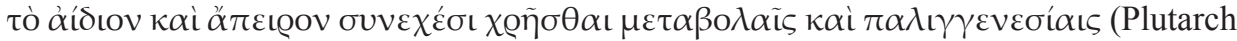
2003:500). 
Because of the religious character Oraculorum is a trifle too pessimistic. of his arguments, Plutarch is forced to Some will also point to the fact that oracles dramaticallyentertain the unthinkable: death as a phenomenon continued to be in use in the spiritual realms! The thought that the for a few centuries after Plutarch and that daemons, perhaps even the gods might it really was the Christian takeover in the be dying ${ }^{31}$, as the ultimate cause behind fourth century that put a final end to it.

the cessation of the oracles! ${ }^{32}$ Was Apollo dead like the great Pan? Trans-mutated perhaps? Or was it only his daemons and faithful celestial servants that had perished, thus robbing the antique world of its access to the gods? Who was to know? De Defectu Oraculorum made one thing clear: Plutarch's book suggests a dramatic decline in the Greek oracle religion and this caused profound concern to its author

\subsection{Too pessimistic?}

Whatever diversity of opinion one may find within De Defectu Oraculorum, all agree in their concern about the decline of the oracles. Throughout the book Plutarch describes this decline in terms of "disappearance" and shows himself extremely concerned about this as a religious development.

Despite this, one should conclude from De Defectu Oraculorum that at least Plutarch signals an existential crisis by the first century already. While some present day scholars would differ from his assessment, there should not be any doubt about his views and concerns. With or without good reason, De Defectu Oraculorum tolls the bell for the beginning of the end of the Greek oracle religion. Whichever way one assesses the author's personal preferences, $D e$ Defectu Oraculorum as a historic literary document proposes an existential crisis in divine communication throughout. It is extremely hard to misread its unequivocal message. The very fact that Plutarch took the trouble to write it all down indicates the importance of its statements. The onus would rest on the sceptics to explain why

Modern critics might object that Plutarch wrote the book filled with serious many were still supporting the oracle concern about the oracle religion at all. religion. One might even argue that some Especially, as the philological context oracles continued to flourish and that the suggests that Plutarch had made his mark description of the situation in De Defectu on the world by the time he wrote it. This

31 Plutarch does not speak in terms of rejuvenation and denial of mortality (cf. FRANKFORT 1958:141-151) but as a fatal and irreversible subjection to the same.

32 Fontelieu (2007:81-82) calls attention to a calculated risk that Plutarch took in writing these words: "The idea that their gods could die, and so were not all powerful either, could not be popular. Plutarch's willingness to address the problem of Greece's ancient oracular traditions was courageous." 
makes it likely that De Defectu Oraculorum self to examine these matters frequently. should be classified as a reflection of a The historical course of events shows further adverse development subsequent that the oracles of the Greek religion to the concerns Plutarch already shared in disappeared and ultimately gave way to De Pythiae Oraculis.

\section{Plutarch and the 21st century}

From the previous section it is clear that Plutarch's view on the cessation of the oracles in the first century cannot be satisfactorily explained in terms of lack of interest and the influences of Roman thought and politics. The data presented from De Defectu Oraculorum show that Plutarch did not have a naturalistic, but a thoroughly religious explanation for the disappearance of the oracles. The gods, willingly or unwillingly, had lost their grip on the ancient places of worship.

Apostolic Christianity, which at that stage confidently claimed active revelation from above. Two thousand years later this once confident religion now faces pressing questions of its own.

Since the days of Nietzsche ${ }^{33}$, many in Western Christianity have gradually started to realise that embracing rationalisticpost-Enlightenmentvaluesinscholarship and worldview has brought on a theological crisis similar to Plutarch's. As a result God's ability to communicate in a reliable way and even his very existence are in doubt. The idea of God has become a superfluous construction in science and Plutarch exhorts his readers and him- scholarship ${ }^{34}$. This approach has not only

Nietzsche came to realise that in the rationalistic worldview, as it had developed from the $17^{\text {th }}$ century, especially since the introduction of Darwinism, there was no longer any need to postulate God. The world and everything in it was explained without him. As a result NIETZSCHE (1887:125) cried in dispair: "Hören wir noch Nichts von dem Lärm der Todtengräber, welche Gott begraben? Riechen wir noch Nichts von der göttlichen Verwesung? - auch Götter verwesen! Gott ist todt! Gott bleibt todt! Und wir haben ihn getödtet! Wie trösten wir uns, die Mörder aller Mörder? Das Heiligste und Mächtigste, was die Welt bisher besass, es ist unter unseren Messern verblutet,-wer wischt diess Blut von uns ab? Mit welchem Wasser könnten wir uns reinigen?" Nietzsche experienced the lack of need to postulate God as a profound bereavement. A century later this would no longer be the case for many who had grown up with the new paradigm and never experienced the old.

PichT (1980:7) explains the grave implications that discarding God as a philosophical construction had in the world of scholarship: "For the representative directions of thought today, philosophy and theology have become historical sciences; the actuality of God is regarded as only a fairytale that one reads about in ancient books. At the same time, however, no one wants to admit this condition for himself. Religion is still needed as an alibi. That is the attitude of the masses in the marketplace who first break into laughter over the raving man (who said God died) but then look at him with dismay. As 
dramatically changed the way theology Roman Catholic Church, Benedict XVI and philosophy operate, but continues (Pontifical Council for the Family 2006) to have severe implications for Western recently called attention to this crisis Christendom as a cultural entity ${ }^{35}$. of revelation: "The causes vary, but the "eclipse" of God, the Creator of man,

Over the past few decades some lies at the root of the profound current Western theologians have considered crisis of the whole truth about man, about and experienced what some call a "God- human procreation and about the family." eclipse." ${ }^{36}$ The present leader of the Christianity is no longer popular ${ }^{37}$. In

Nietzsche expressly says, they do not believe in God, and yet the tidings of God's death have not yet penetrated their ears. They know neither of the reality [Wirklichkeit] of the living God nor of the new reality that has already emerged with the colossal event of God's death. They can take seriously neither the one nor the other. Neither the one nor the other possesses enough obligation for them to shape their lives in one way or another. By that very fact they attest to the truth of the event of which Nietzsche reports."

35 The deliberate eclipse of God in post- Enlightenment scholarship has undermined the cultural and value system of the Western world. PICHT (1980:12) sums up the consequences: "The whole texture of the political, social, and moral order and, in general, the whole edifice of our culture were erected on the foundation that begins to totter with the death of God. Nietzsche already recognizes the splits and fissures in the building, whose collapse was already perceptible to those thinkers in the last century "whose eying suspicion was strong and fine enough for this drama." In the meantime world wars and terroristic rulers have verified Nietzsche's prophecy. But eyes and ears have become so dull that even today alarm over that event of which Nietzsche spoke seldom reaches anyone's thought and conscience. One is happy to have become rid of a bogey, and the spirit continues, like a mole, to burrow its way in order to prepare a future collapse for everything still standing."

36 'God-eclipse' as a phenomenon was initially put on the agenda by Western philosophers like Nietzsche, Buber and Heidegger. In 2006 Pope Benedict XVI showed major concerns about the "eclipse of God" in 2006 (e.g. "Pope Sets Out on a Mission to Halt "Eclipse of God"”, Daily Telegraph (UK) of 7/8/06. See also FABrizio 2007. Earlier, Pope John Paul II (1995, chapter one) called attention for this subject.

37 Particularly in Europe, church membership and adherence are down and traditional Christian doctrines are rejected. This is confirmed by recent research (BARRICK 2007). Results showed that 73 per cent of Americans believe in God or a Supreme Being and 62 per cent of Italians expressed this belief. The French are the least likely with 27 percent agreeing. Cf. PARRIS (2007). Detailed data have been published by the Dutch government (Sociaal en Cultureel Planbureau 2006:8-28). This report contains detailed religious data from the European Social Survey on most European countries and the United States. 
Germany a prominent research unit theocrat, much harder to satisfy than most, at one of the universities captures the particularly about the measure of service spirit: "Empty churches and the pope and involvement of his god Apollo. as celebrity." ${ }^{38} \mathrm{~A}$ similar eclipse was the beginning of the end for Delphi and the ancient world, if not in numbers than on a basic existential level ${ }^{39}$.

\section{Conclusion}

This examination of Plutarch's De Defectu Oraculorum shows that this

Those who find Plutarch's book too primary first century source claims that pessimistic are likely to be tempted to Plutarch and his friends believed that argue along similar lines about the state they experienced a widespread cessation of Christianity in the $21^{\text {st }}$ century. They of oracles in their day. To explain this might propose that with more than one phenomenon, Plutarch did not offer a billion adherents this religion is better off naturalistic, but a thoroughly religious than ever before, yes that even in Western explanation. Plutarch's book maintains countries millions continue to attend that the gods, willingly or unwillingly, church. Those unfamiliar with the historic had lost their grip on the ancient places of developments of Christendom would religious inquiry. According to Plutarch, probably agree with such a statement. the primary cause for the cessation of the The Plutarchs of this generation, howe- oracles was to be sought in the supernatural ver, would be as concerned about the realms of gods and daemons. In a dramatic empty cathedrals as their predecessor climax, Plutarch encouraged his readers was about the deserted chresteria of the to consider that the gods might be dying. first century. Despite remaining activity Within the operation of divine providence, all was not fine. Plutarch was aware of Plutarch introduced secondary causes that a different past. His aim was that all of accomplished the will of the gods, amongst life should be in harmony with the gods. which were the departure of daemons and Of course, as such he was an idealist and the depopulation of Greece. In De Defectu

38 Although there is attention for prominent church leaders in a society dominated by mass media, many church buildings are empty on Sunday. A German research unit summarizes its findings as: "Empty churches and the pope as celebrity" (Bochum University 2008).

39 RESCIGNo (1995) literally uses "the eclipse of the oracles" (L'eclissi degli oracoli) as title for his edition of De Defectu Oraculorum. It is noteworthy that the first persecutors of Christians, Nero and Domitian, were also restorers of the Apolline oracular sanctuary

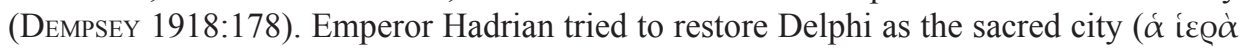
тó $\lambda$ เs). "But this reform had too forced a character. And so, after the Antonines and Severus silence falls upon the Delphic sanctuary. The decline is this time decisive" (DempSey 1918:179). 
Oraculorum Roman influence and culture do not feature as factors at all. On a level of religious experience, Plutarch's ideas prove stimulating for the consideration of the recent "God eclipse" experienced by many in the field of Christian theology. Western Christianity, like Plutarch and his friends, has already made this new eclipse an issue of scholarship, but will it have enough expectancy left to overcome this crisis by actually relating to the realms of the Divine, and 'consult the oracle,' as it were?

\section{Select Bibliography}

Aune, De,

- "Herm. Man. 11.2: Christian false prophets who say what people wish to hear", Journal of Biblical Literature, 97 (1978) 103-104.

BARRICK, A.,

- "Americans More Likely to Believe in God than Europeans", Christianity Today (January 2, 2007).

BARROW, R. H.,

- Plutarch and his times, London: Chatto \& Windus, 1967.

Borgeaud, P.,

- "The death of the great Pan: the problem of interpretation", History of Religions, 22 (1983) 254-283.

BRENK, F. E.,

- ““'A most strange doctrine." Daimon in Plutarch", The Classical Journal, 69 (1973): 1-11.

- In mist apparelled. Religious themes in Frankfort, H., Plutarch's Moralia and Lives, Lugduni Batavorum (Leiden): Brill, 1977.

Curnow, T.,

- The oracles of the ancient world, a comprehensive guide, London: Duckworth, 2004.

Dempsey, T.,

- The Delphic oracle. Its early history, influence and fall, New York: Longmans, Green \& Co., 1918.

DYER, R. R.,

- "The evidence for Apolline purification rituals at Delphi and Athens", The Journal of Hellenic Studies, 89 (1969) 38-56.

ENCYCLOPEDIA BRITTANNICA,

Volume 21, 11th edition, first published in 1911: "Plutarch". Online: http://www. jcsm.org/StudyCenter/Encyclopedia Britannica_Britannica/PIG_POL/ PLUTARCH_Gr_11Xoi_rapxos_c_AD $\mathrm{html}$. The new Encyclopaedia Britannica, 15th edition, volume 9. London: Encyclopaedia Britannica, 2002

Eusebius,

- Praeparatio Evangelica. In: J.P. Migné, Patrologiae Cursus Completus (Seu Bibliotheca Universalis... Omnium S.S. Patrum Doctorum, Scriptorumque Ecclesiasticorum.) Series Graeca. By Jacques Paul Migne. Mytilene: Cultural Heritage Management Lab, University of the Aegean, 2006.

Fabrizio, A.,

"Politics under the Vatican's Glare", The Gay and Lesbian Review Worldwide, 14 (2007) 18.

Fontelieu, S.,

On the death of Pan, unpublished $\mathrm{PhD}$ draft University of Cumbria, 2007.

Fowden, G.,

"The Pagan Holy Man in Late Antique Society", The Journal of Hellenic Studies, 102 (1982) 33-59

- "The Dying God", Journal of the Warburg and Courtauld Institutes, 21 (1958) 141-151.

GREen, G. L.,

"As for Prophecies, They Will Come to an End. 2 Peter, Paul and Plutarch on The Obsolescence of Oracles", Journal for the Study of the New Testament, 82 (2001) 107-122. 
Halsberghe, G., Halsberghe, G. H. \& De Ogilvie, R. M., WAELE, F. J.,

- "TheDate of the «DeDefectu Oraculorum»",

- Standaard geillustreerde encyclopedie van deoudheid. Woordenboek klassieke cultuur, PARIs, M.,

Antwerpen: Standaard Uitgeverij, 1989.

HARRISON, E.,

- "Pan, paneions, panikon", The Classical Review, 40 (1926) 6-8.

Hewitt, J. S.,

- "On the development of the thank-offering among the Greeks", Transactions and Proceedings of the American Philological Association, 43 (1912) 95-111.

IRWIN, W. R.,

- “The survival of Pan”, PMLA, 76 (1961) 159-167.

JoHn PAUL II.

- Euangelium Vitae (1995/3/25), Libreria Editrice Vaticana, online: http://www. vatican.va/holy_father/john_paul_ii/ encyclicals/index.htm.

Jones, C. P.,

- "Towards a chronology of Plutarch's works", The Journal of Roman Studies, 56 (1966): 61-74.

- Plutarch and Rome, Oxford: Clarendon, 1973.

JONES, R. M.,

- The Platonism of Plutarch and selected papers, New York: Garland, 1980.

KLemm, D. E.,

- "Toward a Rhetoric of Postmodern Theology: Through Barth and Heidegger", Journal of the American Academy of Religion, 55 (1987) 443-469.

Nietzsche, F.,

- Die fröhlichen Wissenschaft ("la gaya scienza") (1987) Online: http://www. geocities.com/thenietzschechannel/dfw.htm.

Nilsson, M. P.,

- Cults, myths, oracles and politics in ancient Greece: with two appendices, the Ionian phylae, the phratries. Goteborg: Astroms Forlag, 1986. Phoenix, 21 (1967) 108-119.

- "Do our leaders believe in God? I think we should know that only two prime ministers in two centuries have been strong Christians", The Times (December 22, 2007).

Picht, G.,

"The God of the Philosophers", Journal of the American Academy of Religion, 48 (1980) 61-79.

Plutarch,

- Sur la disparation des oracles, ed. R. Flacelière, Paris: Les Belles Lettres, 1947.

- De defectu oraculorum, ed. W. Sieveking. (Plutarchi Moralia vol.iii, pp. 59-122.) Stuttgart: Teubner, 1972.

L'eglissi degli oracoli, ed. A. Rescigno, Napoli: D'Auria, 1995.

Plutarch's lives, volume 1. The Dryden translation, edited with preface by Arthur Hugh Clough, New York: Random House, 2001.

Moralia, volume $\mathrm{v}$ with an English translation by Frank Cole Babbitt (Loeb Classical Library), Harvard: Harvard University Press, 2003.

Pontifical Council For the FAmily,

- The Family and Human Procreation, 2006. Online: http://www.wf-f.org/ FamilyandHumanProcreation.html.

Russell, D. A.,

- Plutarch. London: Duckworth, 1973.

SwaIn, S.,

- "Plutarch: chance, providence, and history" The American Journal of Philology, 110 (1989) 272-302.

Wood, M.,

- London: The road to Delphi. The life and afterlife of oracles, Chatto \& Windus, 2004.

ZIEGLER, K.,

- Plutarch, über Gott und Vorsehung, Dämonen und Weissagung, Zürich: Artemis, 1952. 